\title{
Management of traumatic macular holes: case report
}

\author{
Tratamento do buraco macular traumático: relato de caso
}

\author{
Oswaldo Ferreira Moura Brasil ${ }^{1}$ \\ Oswaldo Moura Brasil ${ }^{2}$
}

Trabalho realizado no Instituto Brasileiro de Oftalmologia (IBOL) - Rio de Janeiro - Brasil.

${ }^{1}$ Instituto Brasileiro de Oftalmologia (IBOL) - Rio de Janeiro - Brasil. Instituto da Visão da Universidade Federal de São Paulo - UNIFESP - São Paulo (SP) - Brasil.

${ }^{2}$ Instituto da Visão da UNIFESP - São Paulo (SP) - Brasil

Endereço para correspondência: Oswaldo Ferreira Moura Brasil. Praia de Botafogo, 206 - Rio de Janeiro (RJ) CEP 22250-040

E-mail: dico@unisys.com.br

Recebido para publicação em 16.06.2007

Última versão recebida em 20.02.2008

Aprovação em 21.05.2008

Nota Editorial: Depois de concluída a análise do artigo sob sigilo editorial e com a anuência do Dr. Maurício Maia sobre a divulgação de seu nome como revisor, agradecemos sua participação neste processo.

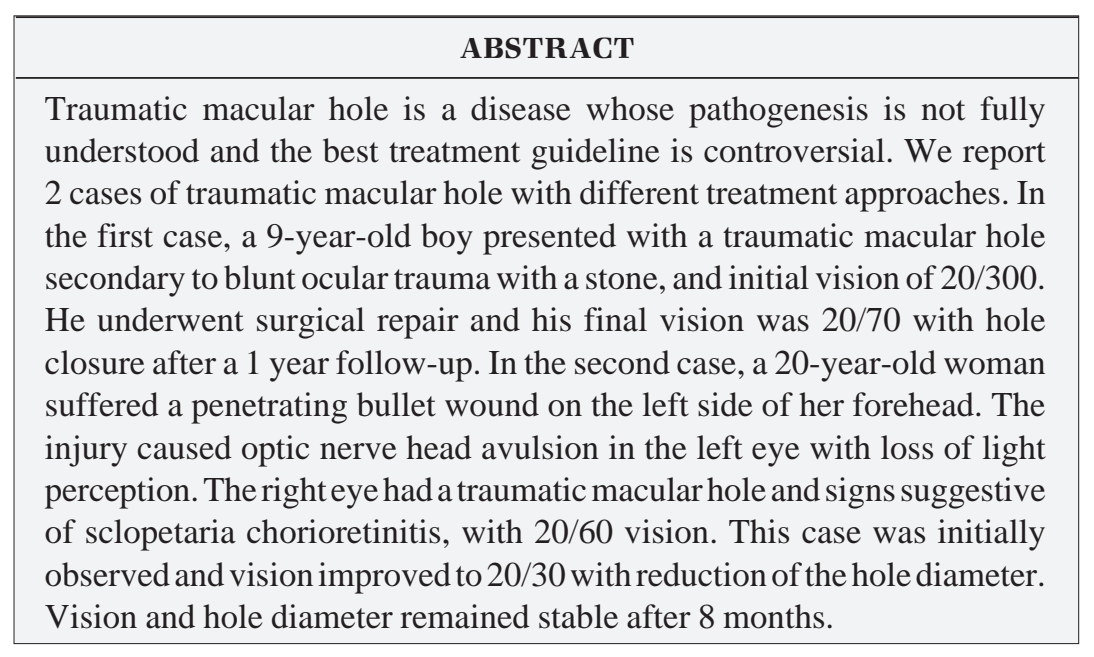

Keywords: Macula lutea/injuries; Macula lutea/surgery; Eye injuries; Visual acuity; Tomography optical coherence; Human; Female; Male; Child; Adult; Case reports [Publication type]

\section{INTRODUCTION}

Although most macular holes are an age-related idiopathic condition, that affect mainly female patients, they may also occur in association with trauma, thus being called traumatic macular holes (TMH). As opposed to idiopathic macular holes, TMH are not associated with gradual onset and the mechanism of their formation remains controversial.

Some authors theorized that the force of the impact transmitted to the macula could result in rupture of the fovea ${ }^{(1)}$. Therefore, if there is a wave of energy transmitted to the fovea, it is supposed that it could be measured. However, high-speed photography and measurement of globe deformation have failed to document this wave of energy in the past ${ }^{(2)}$. Another hypothesis is that sudden vitreous separation could be the cause of $\mathrm{TMH}$, but most cases actually have an attached posterior vitreous ${ }^{(1,3)}$. Optical coherence tomography (OCT) allowed the detection of subclinical inner retinal layer changes that could play a role in the pathogenesis of TMH formation ${ }^{(4)}$.

Besides the mechanism of TMH formation, the decision of whether to operate or simply observe these TMH is also controversial. Several retrospective case series have shown positive outcomes of pars plana vitrectomy for $\mathrm{TMH}^{(3,5-11)}$. On the other hand, many cases of spontaneous closure of $\mathrm{TMH}$ have been reported in the literature ${ }^{(12-19)}$.

We report 2 cases of TMH with different treatment approaches and discuss the management of TMH. 


\section{CASE 1}

A 9-year-old boy was hit by a stone on the right eye (OD) 2 weeks prior to our evaluation. He complained about decreased visual acuity in this eye immediately after the trauma. $\mathrm{He}$ had no previous history of ocular or systemic diseases. His visual acuity was 20/300 in OD and 20/20 in the left eye (OS). Anterior segment examination was unremarkable, except for a dilated pupil in OD due to atropine eyedrops prescribed during the first week after the trauma. A macular hole was detected on fundus biomicroscopy of OD, and posterior vitreous was attached. OCT confirmed the presence of a full-thickness macular hole (Figure 1A). One week after initial evaluation, a standard 3-port pars plana vitrectomy with posterior hyaloid removal, internal limiting membrane peeling and silicone oil tamponade was performed due to lack of compliance regarding postoperative prone-positioning. Three weeks after the procedure, best-corrected visual acuity remained 20/300 and a control OCT showed a closed macular hole under the silicone oil (Figure 1B). Six weeks after the surgery, silicone oil was removed. Three weeks later vision had improved to 20/100 and OCT disclosed a near-normal foveal thickness and contour (Figure 1C). One year after the silicone oil removal, vision is stable at 20/70 and the macular hole remains closed.

\section{CASE 2}

A 20 year-old female was referred to us for ocular examination after clinically stabilization of a bullet wound that had penetrated her forehead 1 month before. She had gone through successful surgical removal of the pellet and had been in intensive care for the last month. She was complaining of decreased visual acuity in both eyes. Her best-corrected visual acuity was 20/60 in OD and she had no light perception in OS. Fundus examination showed a macular hole in OD, where the posterior vitreous was attached, and optic nerve head avulsion in OS. A large area of retinal pigment epithelial atrophy and clumping was also observed in the upper nasal quadrant of OD suggestive of sclopetaria chorioretinitis. OCT confirmed the presence of a TMH in OD (Figure 2A). Due to the severity of the clinical condition of the patient we decided to initially observe the case. One month later, vision had improved to 20/30 J1 in OD and the macular hole had spontaneously reduced, but not closed (Figure 2B). Another 6 months later, vision remained 20/30 $\mathrm{J} 1$ and the macular hole was stable (Figure 2C). Although the patient achieved full clinical recovery, it was decided to observe the TMH for 8 months after the trauma.

\section{DISCUSSION}

Some retrospective case series were analyzed regarding the surgical outcomes of TMH. In 1995, some authors ${ }^{(5)}$ described a $92 \%$ surgical closure rate and a final visual acuity of
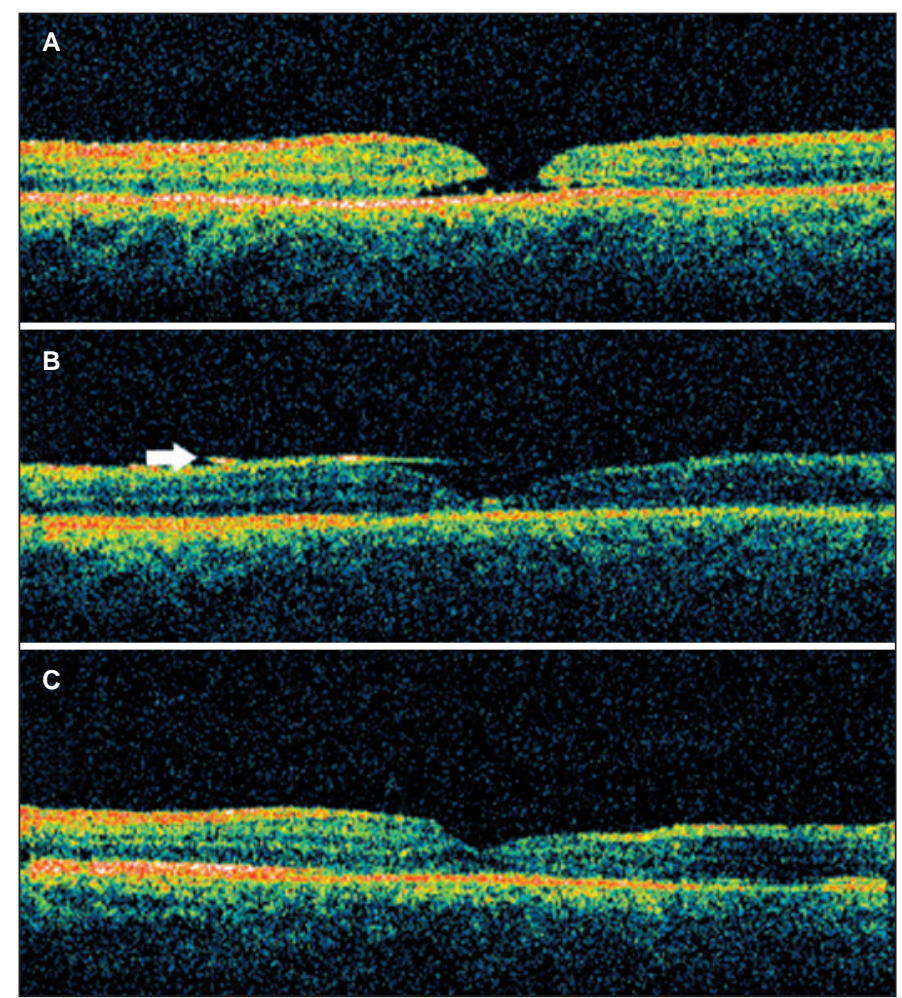

Figure 1 - OCT scans of a 9-year-old boy with traumatic macular hole: (A) full thickness macular hole prior to surgery; (B) closed macular hole under silicone oil (arrow); (C) closed macular hole after silicone oil removal
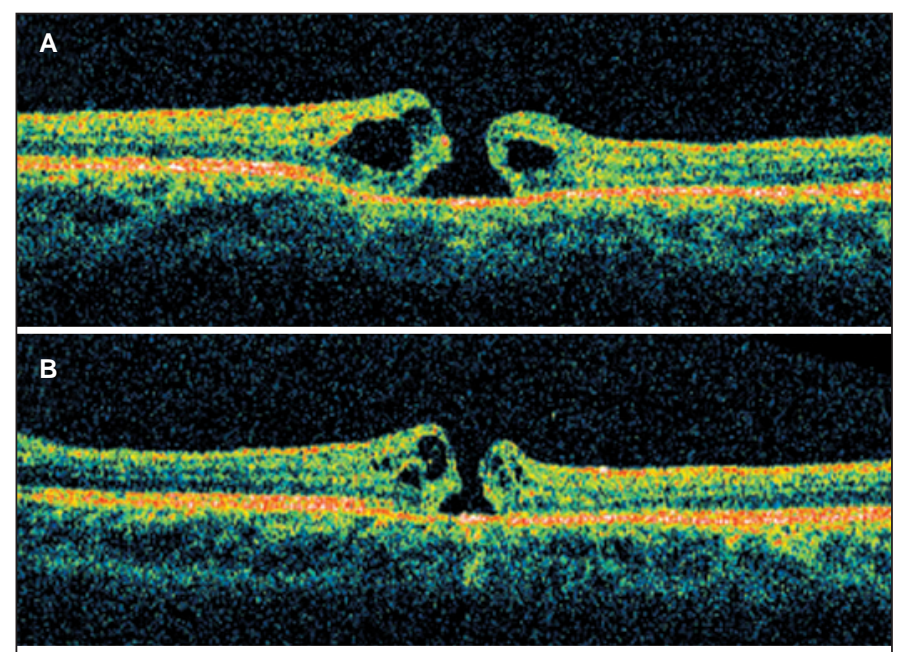

c

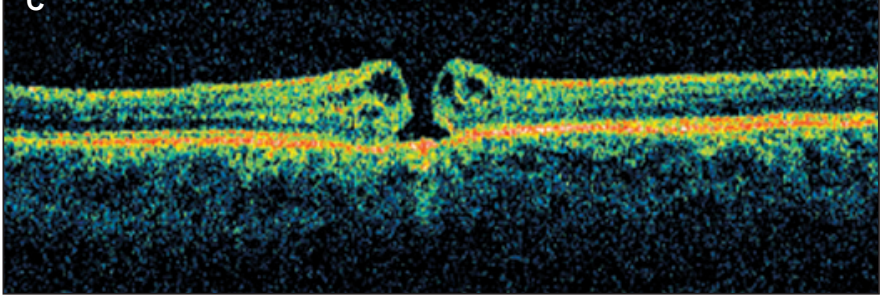

Figure 2 - OCT scans of a 20 -year-old female with traumatic macular hole: (A) full thickness macular hole 1 month after trauma; (B) spontaneous reduction of hole diameter 2 months after trauma; (C) stable hole 8 months after trauma 
20/40 or better in 12 eyes with TMH. Two years later, another group described a series of 14 cases where a $93 \%$ closure rate was observed after surgery and vision improved at least four Snellen lines in every closed hole ${ }^{(7)}$. In 1999, a retrospective case series of 16 eyes with TMH revealed a $94 \%$ closure rate and a vision of $20 / 40$ or better in $38 \%$ of the eyes ${ }^{(9)}$. Later that year, some authors reported 23 cases of TMH that underwent surgical repair. Most macular holes closed after a first surgery and $96 \%$ overall closed after a second surgery. A vision of $20 / 40$ or better was achieved in $48 \%$ of the cases ${ }^{(10)}$. In 2001, a multicenter case series of $25 \mathrm{TMH}$ cases was published, and the authors observed a $96 \%$ closure rate and a vision of $20 / 50$ or better in $64 \%$ of the eyes.

After internal limiting membrane peeling had been introduced to improve the surgical outcomes of macular hole surgery, 17 cases of TMH that underwent surgical repair with this technique were reported ${ }^{(11)}$. A $100 \%$ closure rate and an improvement of 2 or more Snellen lines in $94 \%$ of the eyes was described.

Since these favorable surgical outcomes have started to be reported, some cases of spontaneous resolution with good final vision have also been published. Some authors described 3 cases of TMH that resolved spontaneously 3 to 4 months after the trauma and vision improved to $20 / 20^{(12)}$. Other authors reported 8 cases of spontaneous closure 1 week to 4 months after trauma ${ }^{(15)}$. Half of these cases had final vision of $20 / 40$ or better.

$\mathrm{TMH}$ are less frequent than idiopathic ones, and they have not a well-established management guideline. Since the pathogenesis of TMH is believed to be different from that of idiopathic macular holes, it is not certain that surgery will show an equal benefit. However, several well-documented retrospective case series have actually shown very similar surgical outcomes for idiopathic and TMH. It is supposed that TMH are related to acute hole formation due to traction ${ }^{(20)}$.

It is known that posterior vitreous status is an important factor for surgical decision. In children eyes, it is common for many macular holes to have spontaneous resolution. It is believed that tractional forces that stimulated TMH formation may have also stimulated astrocyte migration to heal the macular holes.

If the TMH has vitreous adhesion to its edges, a conservative approach is advised and these eyes must be initially observed because of the high possibility of spontaneous resolution following complete posterior vitreous detachment, that commonly occurs in their natural history ${ }^{(20)}$.

If the TMH has no vitreous adhesion to the edges of the hole (the posterior vitreous is still detached from the posterior pole) the possibility of spontaneous resolution is $\operatorname{low}^{(14,20)}$.

Additionally, retinal pigment epithelium abnormalities close to the TMH are a common finding in these eyes and would not be a contraindication for surgery ${ }^{(14,20)}$.

Furthermore, it is known that surgical repair may be beneficial to some TMH eyes. However, an observation period of 3-6 months could be recommended in some cases, specially those of small holes with good visual acuity, posterior vitreous adhesion to the TMH edges and young patients, due to the possibility of spontaneous resolution.

\section{RESUMO}

O buraco macular traumático é doença cuja patogênese não é totalmente esclarecida e a melhor conduta terapêutica ainda é controversa. Relatamos 2 casos de buraco macular traumático para os quais adotamos condutas diferentes. No primeiro caso, um menino de 9 anos apresentou buraco macular traumático secundário a trauma ocular contuso com uma pedra, com visão inicial de 20/300. Foi submetido a tratamento cirúrgico e obteve visão final igual a 20/70 com buraco fechado após 1 ano de seguimento. No segundo caso, mulher de 20 anos sofreu traumatismo penetrante por projétil de arma de fogo na fronte, do lado esquerdo. $\mathrm{O}$ trauma causou avulsão do nervo óptico no olho esquerdo com perda de percepção luminososa neste olho. No olho direito apresentou buraco macular traumático e sinais sugestivos de coriorretinite esclopetária, com acuidade visual igual a 20/60. O caso foi inicialmente observado e a visão melhorou para 20/30 com diminuição do diâmetro do buraco. A visão e o diâmetro do buraco mantiveram-se estáveis por 8 meses.

Descritores: Mácula lútea/lesões; Mácula lútea/cirurgia; Traumatismos oculares; Acuidade visual; Tomografia de coerência óptica; Humano; Feminino; Masculino; Criança; Adulto; Relatos de casos [Tipo de publicação]

\section{REFERENCES}

1. Yanagiya, Akiba J, Takahashi M, Shimizu A, Kakehashi A, Kado M, et al Clinical characteristics of traumatic macular holes. Jpn J Ophthalmol. 1996; 40(4):544-7.

2. Delori F, Pomerantzeff O, Cox MS. Deformation of the globe under high-speed impact: it relation to contusion injuries. Invest Ophthalmol. 1969:8(3):290-301.

3. Johnson RN, McDonald HR, Lewis H, Grand MG, Murray TG, Mieler WF, et al. Traumatic macular hole: observations, pathogenesis, and results of vitrectomy surgery. Ophthalmology. 2001;108(5):853-7.

4. Oehrens AM, Stalmans P. Optical coherence tomographic documentation of the formation of a traumatic macular hole. Am J Ophthalmol. 2006;142(5):866-9.

5. Rubin JS, Glaser BM, Thompson JT, Sjaarda RN, Pappas SS, Murphy RP. Vitrectomy, fluid-gas exchange and transforming growth factor-beta-2 for the treatment of traumatic macular holes. Ophthalmology. 1995;102(12):1840-5.

6. De Bustros S. Vitreous surgery for traumatic macular hole. Retina. 1996;16(5): 451-2.

7. Garcia-ArumÍ J, Corscostegui B, Cavero L, Sararols L. The role of vitreoretinal surgery on the treatment of posttraumatic macular hole. Retina. 1997;17(5):372-7.

8. Margherio AR, Margherio RR, Hartzer M, Trese MT, Williams GA, Ferrone PJ. Plasmin enzyme-assisted vitrectomy in traumatic pediatric macular holes. Ophthalmology. 1998;105(9):1617-20.

9. Chow DR, Williams GA, Trese MT, Margherio RR, Ruby AJ, Ferrone PJ, Successful closure of traumatic macular holes. Retina. 1999;19(5):405-9.

10. Amari F, Ogino N, Matsumura M, Negi A, Yoshimura N. Vitreous surgery for traumatic macular holes. Retina. 1999;19(5):410-3.

11. Kuhn F, Morris R, Mester V, Witherspoon CD. Internal limiting membrane removal for traumatic macular holes. Ophthalmic Surg Lasers. 2001;32(4):308-15.

12. Kusaka S, Fujikado T, Ikeda T, Tano Y. Spontaneous disappearance of traumatic macular holes in young patients. Am J Ophthalmol. 1997;123(6):837-9.

13. Parmar DN, Stanga PE, Reck AC, Vingerling JR, Sullivan P. Imaging of a traumatic macular hole with spontaneous closure. Retina. 1999;19(5):470-2.

14. Mitamura Y, Saito W, Ishida M, Yamamoto S, Takeuchi S. Spontaneous closure of traumatic macular hole. Retina. 2001;21(4):385-9. 
15. Yamashita T, Uemara A, Uchino E, Doi N, Ohba N. Spontaneous closure of traumatic macular hole. Am J Ophthalmol. 2002;133(2):230-5.

16. Yamada H, Sakai A, Yamada E, Nishimura T, Matsumura M. Spontaneous closure of traumatic macular hole. Am J Ophthalmol. 2002;134(3):340-7.

17. Yeshurun I, Guerrero-Naranjo JL, Quiroz-Mercado H. Spontaneous closure of a large traumatic macular hole in a young patient. Am J Ophthalmol. 2002;134(4): $602-3$.

18. Menchini U, Virgili G, Giacomelli G, Cappelli S, Giansanti F. Mechanism of spontaneous closure of traumatic macular hole: OCT study of one case. Retina. 2003;23(1):104-6.

19. Carpineto P, Ciancaglini M, Aharrh-Gnama A, Agnifili L, Cerulli AM, Cirone $\mathrm{D}$, et al. Optical coherence tomography and fundus microperimetry imaging of spontaneous closure of traumatic macular hole: a case report. Eur J Ophthalmol. 2005;15(1):165-9.

20. Smiddy WE. The current status of macular hole surgery. Bull Soc Belge Ophthalmol. 1996;262:31-42. 